\title{
PENGARUH TEKNOLOGI PEMBELAJARAN KULIAH ONLINE DI ERA COVID-19 DAN DAMPAKNYA TERHADAP MENTAL MAHASISWA
}

\author{
Agus Kusnayat ${ }^{1,2}$, Moh. Hifzul Muiz ${ }^{3}$, Nani Sumarni ${ }^{4}$, Agus Salim Mansyur ${ }^{5}$, \\ Qiqi Yuliati Zaqiah ${ }^{6}$ \\ 1,3,4,5,6 Program Pascasarjana UIN Sunan Gunung Djati Bandung \\ ${ }^{2}$ Universitas Telkom Bandung, Indonesia \\ email: \\ 1,2 aguskusnayat17@gmail.com, ${ }^{3}$ hifzho78@gmail.com, 4 sumarni.nn78@gmail.com, \\ 5assalam@uinsgd.ac.id, ${ }^{6}$ qqzaqiah67@gmail.com
}

\begin{abstract}
Abstrak
Awal virus corona ditemukan ketika ada penduduk kota Wuhan Cina terjangkit.Penyakit disebabkan oleh virus SARS-CoV-2, sebelumnya orang beranggapan gejala yang dialami sebagai flu biasa, sampai WHO mendeklarasikan pandemi COVID-19. Sampai tanggal 26 Mei 2020, ada 5.406.282 kasus, termasuk 343.562 kematian. Penelitian menggunakan metode mixed methods, dengan melakukan analisa statistik parametris dan non parametris dilanjutkan deskriptif kualitatif. Penelitian di kampus Telkom University dan UIN SGD Bandung menunjukkan sekitar $60.5 \%$ mahasiswa siap beradaptasi dengan penggunaan teknologi pembelajaran perkuliahan online tetapi sekitar $59.5 \%$ keberatan atas tugas yang diberikan dosen yang berakibat tingkat stress mahasiswa sekitar $60 \%$. Kalau hal ini dibiarkan terus akan berakibat fatal dalam perkembangan kejiwaan mahasiswa, dan sebanyak $92 \%$ mahasiswa memilih dan lebih suka perkuliahan tatap muka di kelas di banding perkuliahan online. Sehingga penelitian ini ada hubungan yang erat antara perkuliahan online dengan sikap mental mahasiswa.
\end{abstract}

Kata kunci: Teknologi pembelajaran, kuliah online, COVD-19, stres, kejiwaan

\begin{abstract}
The beginning of the corona virus was discovered when a resident of the Chinese city of Wuhan was infected. The disease was caused by the SARS-CoV-2 virus, previously people thought the symptoms were experienced as ordinary flu, until the WHO declared a COVID-19 pandemic. As of May 26, 2020, there were 5,406,282 cases, including 343,562 deaths. The study uses mixed methods, by doing parametric and non-parametric statistical analysis followed by descriptive qualitative. Research on the campus of Telkom University and UIN SGD Bandung shows that around $60.5 \%$ of students are ready to adapt to the use of online lecture learning technology but around $59.5 \%$ object to the assignments given by lecturers which results in a student stress level of around $60 \%$. If this is allowed to continue it will have fatal consequences in the development of student psychology, and as many as $92 \%$ of students choose and prefer face-to-face lectures in class compared to online lectures. So that this research has a close relationship between online lectures and student mental attitude.
\end{abstract}

Keywords: Learning technology, online lectures, COVD-19, stress, psychiatric

\section{Pendahuluan}

Banyaknya manusia yang berjatuhan dan tak sadarkan diri dengan indikasi umum kesulitan bernafas di berbagai tempat baik dijalanan, rumah, perkantoran, pusat perbelanjaan, tempat wisata, pusat kebugaran dan dilembaga pendidikan serta di berbagai pusat keramaian di kota Wuhan provinsi Hubei-Cina, berita ini dengan cepat tersebar keseluruh Dunia. Belakangan diketahui bahwa mereka terjangkit virus corona, yang ditemukan pertamakali pada November 2019, Penyakit ini dikenal sebagai COVID-19. Penyakit yang disebabkan oleh virus SARS-CoV- 
2, yang sebelumnya orang beranggapan gejala yang dialami sebagai flu biasa, sehingga manusia melakukan aktifitas seperti biasanya dengan berbagai kegiatan yang bervariasi serta diberbagai sektor kehidupan. Terjadinya interaksi manusia yang berasal dari wuhan dengan orang di berbagai Negara, menyebabkan penyakit ini dengan cepat menyebar ke luar Negeri. Pada 11 Maret 2020, Organisasi Kesehatan Dunia (WHO) mendeklarasikan pandemi COVID-19 [1]. Secara global, pada 26 Mei 2020, ada 5.406.282 kasus COVID-19 yang dikonfirmasi, termasuk 343.562 kematian, dilaporkan kepada WHO [2]. Sejak itu, seolah sejarah manusia ditulis ulang. Berbagai rumah sakit menghadapi lonjakan pasien, sehingga menyebabkan jatuhnya layanan medis karena ketidaksiapan sarana dan fasilitas yang dimiliki. Penyakit ini punya karakter sangat cepat penyebarannya, dengan berinteraksi jarak dekat serta bersentuhan dengan penderita, maka sudah bisa mengantarkan seorang terjangkit penyakit ini. Sehingga para ahli kesehatan menyarankan untuk melakukan social distancing, physical distancing dan stay at home. Terus merebaknya penyakit ini ke berbagai tempat di berbagai Negara, mengantarkan kita harus bisa beradaptasi dengan situasi ini. Hal ini meyebabkan banyak pemerintah di berbagai negara melakukan tidakan seperti melakukan karantina, isolasi sosial, perintah diam rumah, penutupan perkantoran, penutupan lembaga pendidikan serta pabrik dll. Untuk melakukan pekerjaan rutin karena sangat dibutuhkankan di lakukan penjadwalan pekerjaan dengan menggunakan protokol kesehatan yang ketat. Hal ini berdampak pasti akan berdampak kepada berbagai sektor kehidupan dengan berbagai implikasinya, termasuk akan terjadi tingkat pengangguran tinggi, yang akan berdampak kepada resesi ekonomi, termasuk dihentikan berbagai acara kenegaraan, kegiatan beribadah di berbagai tempat ibadah serta penangguhan kegiatan olahraga dan salah satunya dijadwal ulangnya Olimpiade Tokyo 2020, termasuk kegiatan berbagai bidang kehidupan lainnya, dengan tanggal yang tidak pasti kapan kegiatan itu dapat dimulai kembali. Penularan yang cepat ini membuat panik dan ketakutan disetiap orang, di tambah dengan informasi yang ditulis diberbagai media sosial dan media massa, sehingga membuat ketakutan akan penyakit coronavirus ini. Hampir semua pemerintah diberbagai negara mengambil tindakan untuk pencegahan dan penghentian penyebaran COVID-19.

Pemerintah Cina dalam hal ini sebagai negara pertama merebaknya COVID-19 ini, melakukan tindakan di semua tingkatan pemerintahannya melalui kegiatan pencegahan interaksi di daerah pademi COVID-19 dengan dunia luar serta melakukan lockdown kota wuhan. Serta melakukan pembangunan rumah sakit cepat untuk menampung pasien yang membludak salah satunya pendirian rumah sakit tempat tinggal Fangcang, serta melakukan deteksi dini dan isolasi kasus yang diduga terindikasi terjangkit. Rumah sakit penampungan Fangcang adalah konsep kesehatan masyarakat yang baru. Mereka diimplementasikan untuk pertama kalinya di Cina pada bulan Februari, 2020, untuk mengatasi penyakit coronavirus 2019 (COVID-19). Rumah sakit penampungan Fangcang di Cjina adalah rumah sakit sementara berskala besar, yang dibangun dengan cepat dengan mengubah tempat umum yang ada, seperti stadion dan pusat pameran, menjadi fasilitas perawatan kesehatan. Mereka bertugas mengisolasi pasien COVID-19 ringan hingga sedang dari keluarga dan komunitas mereka, sambil memberikan perawatan medis, pemantauan penyakit, makanan, tempat tinggal, dan kegiatan sosial. Dan memiliki tiga karakteristik utama mereka (konstruksi cepat, skala besar, dan biaya rendah) dan lima fungsi penting (isolasi, triase, perawatan medis dasar, pemantauan sering dan cepat rujukan, dan kehidupan esensial dan keterlibatan sosial). Rumah sakit hunian Fangcang bisa menjadi komponen kuat nasional tanggapan terhadap pandemi COVID-19, serta epidemi dan kedaruratan kesehatan masyarakat di masa depan [3]. Lockdown wilayah dilakukan juga oleh pemerintah berbagai Negara, seperti misalnya India [4]. Adapun Indonesia tidak melakukan lockdown skala Negara, hanya beberapa wilayah tertentu melalukannya walaupun ditentang oleh pemerintah pusat, DKI Jakarta sebagai Ibukota Negara melakukan proses pencegahan bertahap sampai akhirnya melakukan pembatasan sosial berskala besar (PSBB) adalah istilah kekarantinaan kesehatan di Indonesia yang didefinisikan sebagai pembatasan kegiatan penduduk dalam suatu wilayah yang diduga terinfeksi penyakit atau terkontaminasi untuk mencegah kemungkinan penyebaran penyakit. Walaupun peraturan Gubernur DKI Jakarta dengan berbagai kebijakannya, serta fakta yang ada. Banyak para ahli menerangkan bahwa Indonesia sudah mengalami kondisi 
mengkhawatirkan terhadap COVID-19 ini, sehingga disarankan kepada pemerintah untuk melakukan lockdown, sebagai upaya memutus penyebaran penyakit ini [5].

Sebagaimana Negara lain, Indonesia juga membuat kebijakan meliburkan seluruh lembaga Pendidikan untuk beraktifitas di kelas bersama secara offline. Akan tetapi seluruh perguruan tinggi diminta menerapkan teknologi pembelajarn untuk perkuliahan via online. Hal ini bertujuan sebagai upaya mencegah penularan COVID-19. Hal ini bukan menjadi sebuah masalah bagi beberapa perguruan tinggi yang memiliki sistem akademik berbasis daring. Namun akan menjadi masalah bagi perguruan tinggi yang belum memiliki akademik berbasis daring. Kuliah dengan sistem online bertujuan memberikan kesempatan kepada seluruh warga Negara Indonesia untuk dapat menikmati proses pembelajaran dimana saja berada. Hal ini pernah diprediksikan oleh Thomas L. Friedman bahwa kedepan perkuliahan mahasiswa cukup duduk di depan komputer yang tersambung dengan jaringan internet dimana saja, sudah bisa melakukan proses perkuliahan walaupun tidak menyatakan secara spesifik akibat COVID-19. Hanya komentar yang sangat terkenal darinya yaitu pernyataan bahwa "The World is Flat" [6]. Hal ini menunjukkan semakin lama, border suatu negara dengan negara lain semakin menghilang.Termasuk pendidikan dapat dirasakan oleh semua orang, melalui proses belajarmengajar melalui internet, salah satunya kuliah online ini, sehingga mendorong para dosen dan mahasiswa lebih kreatif,efektif serta membangun jejaring yang luas dengan berbagai orang baik sebidangnya maupun interbidangnya diberbagai belahan dunia [7].

Sejalan dengan penggunaan teknologi pembelajaran online ini. National University, Costa Mesa, California, USA melakukan penelitian di tiga fakultas. Sebagai proyek percontohan dalam membuat kerangka kerja untuk pengajaran online dan pengembangan profesional dalam pendidikan tinggi. Hasilnya terlihat peningkatan dalam keterlibatan siswa, kepuasan, pembelajaran dan prestasi. Tiga fakultas disurvei siswa untuk menentukan keterlibatan dan kepuasan mereka dan menemukan siswa untuk merespons secara positif kegiatan ini dan terlihat keterlibatan para mahasiswa, keterlibatan antar mahasiswa dalam tugas yang diberikan dan aktifnya mahasiswa ke instruktur dalam pembelajaran. Tiga fakultas yang diteliti menunjukkan bahwa nilai menunjukkan ada perubahan hasil sebelumnya. Seorang profesor melihat nilai ratarata meningkat sebesar 11 persen. Profesor lain melihat nilainya naik 8 persen. Dia juga menemukan bahwa penilaian belajar siswa meningkat 0,57. Kedua fakultas menghubungkan peningkatan ini untuk efektivitas strategi pengajaran yang digunakan [8]. Penelitian lain yang dilakukan bertujuan untuk menganalisis pembelajaran daring pada masa works from home (WFH) akibat penyebaran pandemic Coronavirus Disease, menujukan efektifitas pembelajaran daring dengan capaian yang signifikan seiring dengan tuntutan mewujudkan pemimpin digital pendidikan tinggi abad 21, menyimpulkan bahwa pembelajaran daring terbukti efektif dilaksanakan pada masa WFH akibat pandemik COVID-19 [9].Situasi yang sama dialami sistem pendidikan di Georgia pada semester musim semi 2020 mengalami berubah, setelah ditemukannya kasus pertama infeksi COVID-19.Georgia menjadi salah satu dari 188 negara di seluruh dunia yang telah menangguhkan proses pendidikan tatap muka. Para peneliti mempelajari kemampuan Negara dan penduduknya beradaptasi dengan pemggunaan teknologi pembelajaran jarak jauh, penggunaan platform yang tersedia dengan dukungan pemerintah, seperti aplikasi portal online, sekolah TV serta penggunaan aplikasi yang tawarkan di internet seperti Zoom, Slack dan Google Meet, Edu-Page. Hasilnya terkonfirmasi bahwa transisi cepat ke bentuk pendidikan online berjalan dengan sukses dan pengalaman yang diperoleh dapat digunakan di masa depan. Pengalaman dan studi bisa bermanfaat bagi negara lain itu belum menemukan cara transisi [10].Seiring dengan perkembangan teknologi pembelajaran ini, maka pembelajaran jarak jauh berbasis internet, disukai oleh generasi Z. Generasi ini sering disebut juga generasi internet atau digital natives, merupakan anak - anak yang lahir pada tahun 1995 - 2009, generasi ini lahir pada jaman teknologi yang sudah semakin canggih sehingga gaya belajarpun berbeda. Gaya belajar anak generasi $\mathrm{Z}$ yaitu menyukai format audio - visual, bergantung pada teknologi, mudah memahami contoh yang lebih akurat, konkret, fakta dan bermanfaat sehingga agar tujuan dari pembelajaran dapat tersampaikan dengan baik maka salah satu inovasi yang dapat dilakukan menggunakan media pembelajaran yaitu video pembelajaran. Selain itu sudah banyak sekali 
penelitian yang mengatakan bahwa video pembelajaran efektif digunakan dalam proses pembelajaran bagi anak generasi Z [11].

Adapun aplikasi dalam pembelajaran online yang digunakan oleh para dosen dan mahasiswa setiap tempat berbeda-beda. Pengajaran onlineyang dilakukan di berbagai perguruan tinggi termasuk di india diminta cepat beradaptasi dengan menggunakan berbagai aplikasi yang ditawarkan termasuk aplikasi zoom. Dapat meningkatkan kehadiran dan juga meningkatkan keterlibatan secara signifikan jika diberikan pelatihan yang rutin serta akses internet yang optimal dan pelatihan cara penggunaan aplikasi serta pemanfaatan akses internet dalam pembelajaran dan penyelesaian persoalan seputar perkuliahan [12]. Pembelajaran online merupakan salah satu solusi yang dibutuhkan oleh tenaga pendidik dan mahasiswa di masa pandemi ini. Proses pembelajaran online dengan menggunakan zoom sebagai alternatif pemecahan masalah kegiatan pembelajaran pada mata kuliah sosiologi dan antropologi. hasil penelitiannya dengan menggunakan zoom mempermudah dalam mengumpulkan data kualitatif karena lebih efektif biaya [13]. Penggunaan aplikasi zoom hasil penelitian di Bina Bangsa Serang menunjukan bahwa penggunaan zoom lebih baik dari pada kelas yang diberikan penggunaan WA Group [14]. Setiap Daerah, penggunaan teknologi pembelajaran online dengan menggunaan aplikasi whatsapp grup jauh lebih diminati dalam pembelajaran online ini, di kota Kendari mislanya aplikasi yang disuka dalam kuliah online, sebanyak 56 mahasiswa atau 91,8\% mahasiswa memilih aplikasi , sebanyak 4 mahasiswa atau 6,5\% mahasiswa memilih aplikasi zoom dan sebanyak 1 mahasiswa atau 1,6 $\%$ mahasiswa memilih aplikasi email [15]. Banyaknya platform pembelajaran daring yang dapat digunakan untuk aktivitas belajar mengajar, menimbulkan preferensi platform pembelajaran daring bagi mahasiswa. Metode Analitik Hirarki Proses (AHP) digunakan untuk merumuskan bobot dan peringkat setiap pilihan platform pembelajaran daring. Hasil penelitian menunjukkan bahwa platform pembelajaran daring yang menjadi preferensi mahasiswa UGM berdasarkan kriteria-kriteria persepsi responden tersebut memunculkan alternatif platform pembelajaran daring yang paling diminati oleh mahasiswa UGM adalah elisa dengan perolehan bobot akhir sebesar 0,27 diikuti oleh platform elok, classroom, zoom, meets, dan terakhir webex [16].

Faktanya, khusus di Indonesia atau beberapa perguruan tinggi yang mirip permasalahannya merasa belum siap menggunakan teknologi pembelajaran dengan sistem daring atau online. Bahkan dengan diterapkannya sistem ini ditemukan ada mahasiswa yang terganggu kejiwaannya, stress dan tidak dapat mengikuti proses pembelajaran dengan baik dan benar. Hal ini menjadi masalah baru yang harus dicarikan solusinya. Beberapa permasalahan yang muncul yang berkaitan dengan sistem pembelajaran via online, baik berupa kesiapan mahasiswa, penguasaan teknologi, kendala-kendala lain yang dialami selama menggunakan sistem ini, akan terjawab dalam penelitian ini. Sehingga evaluasi bisa dilakukan untuk meminimalisir kendala dan permasalahan yang dihadapi mahasiswa selama menggunakan cara ini. Dengan demikian Kedepannya pembelajaran via online akan semakin baik dan tercapai hasil pendidikanyang sesuai dengan cita-cita mulia bangsa Indonesia yang terdapat dalam pembukaan UUD 1945 alinea ke-4, salah satunya adalah mencerdaskan kehidupan bangsa.Perubahan metode pembelajaran dengan cara klasikal dan tatap muka menjadi metode online mendapatkan berbagai reaksi dari mahasiswa. Waktu yang singkat, tugas yng banyak, jumlah kuota, kondisi sinyal membuat mahasiswa berjibaku mempersiapkan semuanya dengan baik. Selain itu diketahui juga bahwa program belajar melalui via online mempunyai hidden skill yaitu kemampuan untuk menguasai teknologi dan menggunakannya dengan benar. Di sisi lain kebijakan penutupan sementara lembaga pendidikan dengan berbagai fasilitas pendukungnya dalam jangka pendek dan jangka menengah membuat banyak mahasiswa terdampak, khususnya mereka yang memiliki tinggal di daerah dengan keterbatasan infrastruktur dan daya dukung lainnya semakin memperluas kesenjangan digital. penelitian ini menggali dan menemukan beberapa masalah pendidikan yang dipicu oleh perubahaan cepat menuju pembelajaran online dengan merefleksikan beberapa pelajaran yang mungkin dipelajari dari periode krisis ini untuk 
dunia pendidikan, termasuk kebutuhan untuk itu mengatasi masalah akses dan fungsionalitas, keterampilan guru, kompetensi siswa, pembagian sumber daya dan kolaborasi global untuk mendidik dunia yang lebih baik [17].

Hasil dari penelitian ini mengungkapkan beberapa faktor yang dapat menciptakan pengalaman belajar yang menarik bagi pembelajar online. Bagaimana cara mengoptimalkan potensi serta menciptakan dan memelihara lingkungan belajar yang positif, membangun komunitas belajar, memberikan umpan balik yang konsisten secara tepat waktu dan menggunakan teknologi yang benar untuk mengirimkan dan menjawab tugas yang diberikan. [18]. Penelitian ini juga bertujuan untuk menyoroti peran kecerdasan emosional dan stabilitas emosi para mahasiswa dalam menghadapi krisis secara umum dan krisis COVID-19 yang ada yang memiliki dampak global ini. Mengungkapkan dampak fisik dan psikologis pada manusia terutama mahasiswa di seluruh dunia. Juga untuk mengklarifikasi pentingnya kecerdasan emosional dan stabilitas emosi dalam menghadapi ketakutan dan kecemasan yang ada yang disebabkan oleh virus korona serta permasalahan pada perkuliahan online [19]. Tingkat kecemasan atau depresi pernah dirasakan sebelumnya juga ketika merebaknya berbagai virus termasuk virus Ebola, dukungan psikososial mungkin diperlukan untuk orang dengan pengalaman terkait Ebola. Bagaiman cara mencegah, mendeteksi, dan menanggapi kondisi kesehatan mental [20].Layanan kesehatan mental online yang digunakan untuk pendemi COVID-19 serta memfasilitasi pengembangan intervensi darurat publik seperti Negara Cina dan beberapa Negara lainnya, hal ini lakukan yang pada akhirnya dapat meningkatkan kualitas dan efektivitas intervensi darurat yang dilakukan oleh pemerintah dalam menangani dampak sosial dari merabaknya wabah ini [21].Fakta lain menunjukkan penyakit coronavirus sudah menularkan ke penduduk Makau, Hong Kong, dan Negara Asia dan Eropa lainnya. Penyebaran COVID-19 ini telah meningkatkan perhatian Internasional. Pasien, tenaga kesehatan, dan masyarakat umum termasuk siswa di berbagai lembaga pendidikan berada di bawah psikologis seperti kecemasan, ketakutan, depresi, dan insomnia. Intervensi krisis psikologis memainkan peran penting dalam penyebaran penyakit secara keseluruhan. salah satu yang dilakukan Komisi Kesehatan Nasional Cina telah menyerukan panggilan darurat psikologis membentuk tim yang terdiri dari para pakar dibidannya untuk menyusun pedoman dan artikel / video pendidikan kesehatan masyarakat dengan layanan kesehatan mental online. Para ahli telah mencapai konsensus tentang penerimaan pasien dengan penyakit mental yang parah selama wabah COVID-19 di lembaga kesehatan mental termasuk layanan mental untuk para pelajar dan mahasiswa [22]. Beberapa waktu yang lalu merebak virus MERS, hal yang sama juga dilakukan penanganan penyakit harus hati-hati karena banyak staf medis yang melakukan tugas yang berhubungan dengan MERS memiliki risiko lebih tinggi tertular dan faktanya dalam penyebaran COVID-19 inipun terjadi, banyak tenaga kesehatan baik dokter maupun perawat yang terjangkit dan tidak sedikit yang meninggal termasuk di Indonesia pada dasarnya di dorong karena faktor stres yang meninggi juga. Karena itu, harus ada kesadaran lebih lanjut tentang pandemi ini target perawatan psikiatris, dan intervensi psikiatrik yang cepat dan berkesinambungan untuk mengurangi berjangkitnya penyakit menular yang berpotensi mengancam kehidupan [23].

Wabah COVID-19 telah menunjukkan banyak masalah dengan pemberian intervensi psikologis di Cina. Di sini kami telah menyarankan cara-cara agar pemerintah dapat membangun dan meningkatkan sistem intervensi berdasarkan saran ilmiah yang baik, untuk secara efektif menangani masalah kesehatan mental yang disebabkan oleh keadaan darurat kesehatan masyarakat [24]. Perlindungan psikologis mental kesehatan tenaga medis telah diinisiasi di Cina. Pengalaman dari darurat kesehatan masyarakat ini harus menginformasikan efisiensi dan kualitas intervensi krisis Cina di masa depan [25]. Dalam setiap bencana biologis, tema-tema ketakutan, ketidakpastian, dan stigmatisasi adalah hal biasa dan dapat bertindak sebagai hambatan untuk intervensi medis dan kesehatan mental yang sesuai. Berdasarkan pengalaman dari pneumonia baru yang serius di masa lalu wabah secara global dan dampak psikososial dari virus, pengembangan dan implementasi penilaian kesehatan mental, dukungan, perawatan, dan layanan adalah tujuan penting dan mendesak bagi kesehatan menanggapi wabah COVID-19 ini [26]. Banyak Perguruan Tinggi melakukan penanganan mental para mahasiswanya melalui layanan 
mental yang di bentuk baik karena ada mahasiswa yang terjangkit atau mahasiswa yang stress, sehingga mendorong manajemen mengambil berbagai upaya salah satunya pada level fakultas yaitu pelatihan dan kurus singkat online penggunaan teknologi serta bertukar pengalaman diantara mereka peringan beban kuliah serta bantuan berupa quota internet kepada para mahasiswa bahkan ada perguruan tinggi yang melakukan absensi online mengecek kesehatan para civitas akademiknya setiap hari, agar mengetahui kondisi bagaimana dampak COVID-19 di institusi yang dikelolanya. Meskipun COVID-19 telah menciptakan disonansi kognitif pada mahasiswa terhadap berbagai situasi yang mereka hadapi dalam kehidupan sehari-hari mereka dalam hubungan dengan masyarakat, keluarga, dan pengajaran dan pembatasan perjalanan, telah dan tetap diingatkan untuk dijalankan sebagaimana arahan yang diberikan pemerintah, apalagi saat ini kebijakan kearah New normal diberbagai negara telah diterapkan termasuk Indonesia ke depan.

Wabah COVID-19 telah memicu minat penelitian baru diberbagai bidang untuk menemukan cara pengobatan dan pecegahannya, termasuk penelitian dampak psikologis yang ditimbulkan ini kepada para profesional kesehatan, pasien, dan layanan publik termasuk Pendidikan. Intervensi dalam penanganan dampak psikologis terhadap pasien telah dilakukan seperti penanganan perilaku depresi, kecemasan, dan susah tidur melalui aplikasi WeChat, juga telah dikembangkan kecerdasan buatan (AI) program telah digunakan sebagai intervensi untuk krisis psikologis selama pendemi COVID-19 ini. Sebagai contoh, individu yang berisiko bunuh diri bisa diakui oleh program ini dengan memonitor dan menganalisis pesan yang diposting di Weibo, dan mengingatkan relawan yang ditunjuk untuk bertindak sesuai itu. Secara umum, mental online layanan kesehatan yang digunakan untuk COVID-19 bisa berjalan efektif [27]. Dampak lain dari permasalahan mental ini seperti kecemasan, stres, depresi, susah tidur, seperti kemarahan dalam perang melawan SARS dan Ebola dimasa lalu. Menanggapi masalah kesehatan mental masyarakat Cina, Komisi Kesehatan Nasional Cina telah mengeluarkan pedoman untuk lokal berwenang untuk mempromosikan intervensi krisis psikologis terhadap akibat COVID19. Sebagai tambahan, banyak pusat konseling psikologis telah menyiapkan hotline khusus untuk disediakan layanan konseling psikologis bagi mereka yang membutuhkan termasuk diberbai kampus [28]. Menggaris bawahi dampak psikologis, bukti empiris cukup terbatas sejauh ini, disebabkan oleh kurangnya data sebagai sumber acuan penelitian masalah ini untuk beban kesehatan mental orang-orang Cina selama wabah COVID-19 berdasarkan survei berbasis web. Mereka mendokumentasikan usia itu, pekerjaan, dan perhatian terhadap COVID-19 adalah prediktor signifikan dari kecemasan umum dan kualitas tidur. Hanya berdasarkan latar belakang ini, kami bertujuan untuk mengeksplorasi peran pengalaman dan sikap karantina terhadap COVID-19 dalam mempengaruhi keseluruhan distribusi kesejahteraan psikologis di antara orang dewasa di Cina. Pekerjaan kami melengkapi literatur yang ada dalam dampak psikologis wabah penyakit dengan cara, berikut dan tekanan psikologisnya [29].

\section{Metode Penelitian}

Metode penelitian yang dilakukan menggunakan penelitian mixed methods, yang pertama melakukan analisa statistik parametris dan non parametris dari data kuantitatif bedasarkan data statistik hasil pengolahan data yang diberikan, kemudian melakukan deskriptif kualitatif dengan menggambarkan dampak kuliah online kepada para mahasiswa. Melalui pertanyaan seberapa antusiasnya mahasiswa menggunakan teknologi pembelajaran dalam mengikuti kuliah online?,berapa banyak mahasiswa yang mengalami kesulitan menggunakan teknologi pembelajaran berupa aplikasi yang dipakai kuliah online?, Seberapa besar tugas yang dibebankan serta tingkat stress yang dialami mahasiswa dalam perkuliahan online ini? Serta seberapa banyak respon yang diberikan dari pilihan kuliah online atau kuliah tatap muka dikelas?. Langkah penelitian berikutnya yang dilakukan dengan teknik pengumpulan data melalui pengisian kuesioner yang di berikan kepada mahasiswa [30]. Sampel pada penelitian ini adalah mahasiswa Telkom University Bandung (Tel-U), Universitas Islam Sunan Gunung Djati Bandung (UIN) kemudian dilakukan analisis data, penyajian data, dan kesimpulan. Teknik pengumpulan data lewat survey, merupakan penelitian yang sumber data dan informasi utamanya diperoleh dari 
responden sebagai sampel penelitian dengan menggunakan kuesioner sebagai instrumen pengumpulan data, kuesioner berupa form dalam bentuk softfile di kirim kepada para mahasiswa yang sudah didapatkan identitasnya berupa no. HP dan di kirim melalui Whatsapp Grup, form kuesioner yang terkumpul di olah dengan menggunakan Software Excel untuk mendapatkan data berupa tampilan grafik, sehingga dari data penelitian ini dapat dieksplorasi untuk dibuatkan deskripsinya dampak kuliah online dihubungkan dengan sikap kejiwaan yang muncul dari para mahasiswa. Kemudian di carikan penguatan melalui referensi yang didapat dari penelitian kejiwaan yang telah dilakukan dalam menghadapi kasus yang sama atau mirip untuk kemudian ditarik benang merahnya untuk dicarikan solusinya.

\subsection{Pertanyaan Kuesioner}

Berdasarkan bentuk pertanyaannya, kuesioner dapat dikategorikan dalam dua jenis, yakni kuesioner terbuka dan kuesioner tertutup. Kuesioner terbuka adalah kuesioner yang memberikan kebebasan kepada objek penelitian untuk menjawab. Sementara itu, kuesioner tertutup adalah kuesioner yang telah menyediakan pilihan jawaban untuk dipilih oleh objek penelitian. Seiring dengan perkembangan, beberapa penelitian saat ini juga menerapkan metode kuesioner yang memiliki bentuk semi terbuka. Penelitian ini dengan pertanyaan terbuka dengan menjawab pilihan jawaban yang sudah dibuat peneliti dengan cara menceklis jawaban: Sangat setuju (SS), Setuju (S), Ragu-ragu (RR), Tidak setuju (ST), Sangat Tidak Setuju (STS). Adapun Pertanyaan yang ada di kuesioner seperti terlihat pada tabel 1 .

Tabel.1 Pertanyaan Kepada Mahasiswa

\begin{tabular}{cl}
\hline \multirow{2}{*}{ No } & \multicolumn{1}{c}{ PERTANYAAN } \\
\hline 1 & Saya sangat antusias mengikuti kuliah online \\
\hline 2 & Saya kesulitan dengan penggunaan aplikasi kuliah online \\
\hline 3 & Tugas dosen di kuliah online yang lebih banyak daripada perkuliahan offline \\
\hline 4 & Kalau memikirkan tugas kadang saya susah tidur \\
\hline 5 & Saya suka kuliah offline dikelas langsung dari pada kuliah online \\
\hline
\end{tabular}

\subsection{Pengolahan Data menggunakan Software Excel}

Excel merupakan salah satu produk Microsoft 2016 yang berupa lembar kerja dalam bentuk spreadsheet. Pada umumnya Microsoft excel digunakan untuk membantu user dalam mengolah data. Adapun data kuesioner ini bersumber dari mahasiswa Telkom University sebanyak 31 responden dari 35 mahasiswa yang di targetkan dan Universitas Islam Negri Sunan Gunung Djati sebanyak 32 responden dari 35 mahasiswa yang ditargetkan dan nilai prosentanse pada grafik dilakukan pembulatan sesuai standar tetapi hasil akhir di data primer tetap $100 \%$.

\section{Hasil dan Pembahasan}

\subsection{Data Hasil pengolahan}

Hasil dari pengolahan data menggunakan excel dari jawaban - jawaban para mahasiswa, sesuai pertanyaan-pertanyaan yang dibuat, ditampilkan dalam bentuk grafik, yang bisa dilihat pada gambar 1 dan gambar 2 dibawah ini. Sebagai informasi untuk analisa dari hasil pengolahan data ada penggabungan kategori, katagori sangat setuju (SS) dan setuju (S) digabung menjadi satu, katagori ragu-ragu tersendiri dan katagori gabungan tidak setuju (TS) dan sangat tidak setuju (STS) menjadi satu juga. 


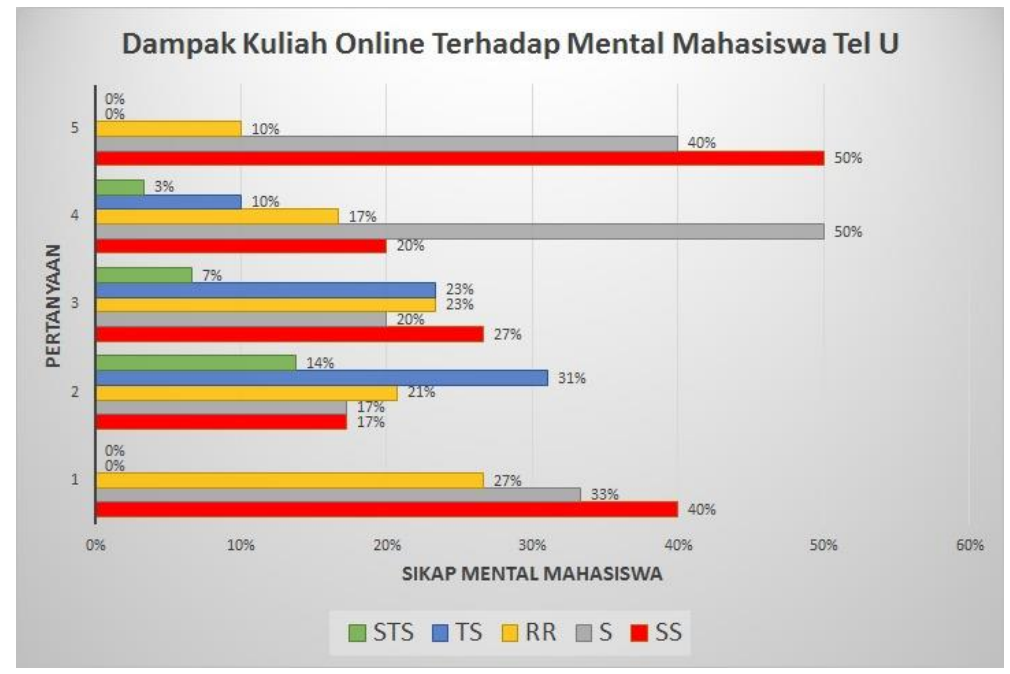

Gambar 1. Dampak Mental Mahasiswa Telkom University Terhadap Kulaih Online

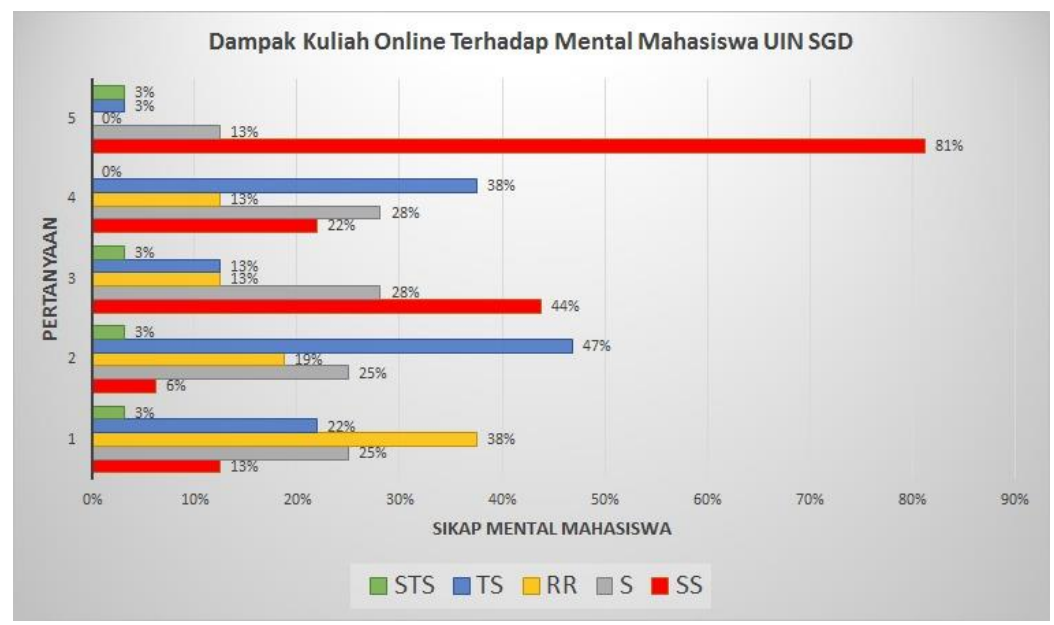

Gambar 2. Dampak Mental Mahasiswa UIN SGD Bandung Terhadap Kulaih Online

\subsection{Deskripsi Hasil Penelitian}

1) Pertanyaan : Saya sangat antusias mengikuti kuliah online

Para mahasiswa merespon pertanyaan ini dengan bervariasi dari gambar 1 dan gambar 2, grafik yang ditampilkan untuk mahasiswa Telkom University sebanyak, $73 \%$ sangat mendukung, sekitar $27 \%$ menjawab ragu-ragu, dan tidak ada yang menjawab tidak setuju. Adapun untuk mahasiswa UIN SGD Bandung, sebanyak $48 \%$ sangat mendukung, sekitar $34 \%$ menjawab ragu-ragu, dan sebanyak $28 \%$ yang menjawab tidak setuju. Analisa dari data tersebut mahasiswa Telkom University bisa melakukan adaptasi dengan kondisi ini artinya perkuliahan online bukan menjadi permasalahan, yang kalau kita melihat, wajar karena mereka yang masuk universitas ini secara daya dukung dari berbagai sisi lebih siap, termasuk dukungan finansial sehingga bisa melakukan percepatan menyediaan peralatan yang dibutuhkan dalam perkuliahan online disamping faktor lainnya. Adapun $27 \%$ mahasiswa yang ragu-ragu, bisa dianalisa bahwa hal ini bisa kebalikan kemampuan dari $73 \%$, atau karena kekagetan perubahan sistem yang cepat karena pandemi COVID-19 ini sehingga belum siap beradaptasi atau karena hal lainnya semisal terjebak kena lockdown daerah melalui peraturan PSBB, sehingga harus tinggal dirumah saudaranya yang akses internet belum optimal. Sedangkan dari data diatas untuk 
mahasiswa UIN SGD Bandung sebanyak $48 \%$ sangat mendukung, sekitar $34 \%$ menjawab ragu-ragu, dan sebanyak $28 \%$ yang menjawab tidak setuju. Analisa dari data tersebut, sekitar $48 \%$ mahasiswa siap beradaptasi dengan baik bisa alasannya sama denagn mahasiswa Tel-U, $28 \%$ mahasiswa belum siap hal ini bisa dikarenakan beberapa faktor salah satunya daya dukung finansial, tentunya ada faktor lainnya, yang menarik dan tentunya perlu didalami bahwa mahasiswa yang menjawab ini, biasanya mahasiswa berasal dari daerah akan tetapi diantara mereka ada yang memiliki kemampuan akademis yang baik dan sangat baik, hal ini menjadi masukkan buat pihak perguruan tinggi untuk melakukan treatment yang tepat. Adapun sebanyak $34 \%$ mahasiswa menjawab raguragu, hal yang sama dengan $27 \%$ mahasiswa Telkom University, dan bisa juga alasan yang sama bisa juga alasan yang lain dari kedua perguruan tinggi tersebut yaitu dampak sebuah suasana kebebasan kampus yang mendorong banyak mahasiswa berinteraksi dengan teman-temannya di berbagai forum dari berbagai kalangan dan latarbelakang budaya yang berbeda, baik budaya positif maupun negatif. Hal yang membahayakan jika efek dari budaya negatif ini, sehingga bisa menjerumuskan mahasiswa kepada sikap malas mengikuti perkuliahan dan sering bolos baik dalam perkuliahan normal maupun perkuliahan online seperti ini termasuk bermaslah dengan dosen, sejawatnya bahakan institusi.Analisa yang lebih mendalam terhadap mahasiswa yang ragu dan tidak siap ini, dari sebagaian besar dari mereka menjadi indikator awal terprediksinya mahasiswa yang gagal menyelesaikan kuliah atau akan drop out, kalaupun berlanjut kuliahnya menggunakan waktu maksimal yang diberikan kampus. Akhir analisa dari pertanyaan ini, sesungguhnya apapun yang terjadi baik mahasiswa maupun dosen atau tenaga administerasi sekalipun, harus siap dengan kondisi ini, baik karena sebab penyebaran penyakit atau alasan lainnya yang menyebabkan seperti ini. Sejak tahun 2005 Thomas L. Friedman sudah memprediksikan tentang hal ini dengan menyatakan The world is Flate. Hal yang lebih spektakuler dalam sejarah Kenabian yaitu seorang ahli pada zaman Nabi Sulaiman A.S bisa memindahkan singgasana ratu Balqis dengan memerlukan waktu lebih cepat dari kedipan mata sekalipun [31]. Sedangkan perkuliahan online baru bisa memindahkan gambar dan pesan yang disampaikan di dunia virtual/maya.

2) Pertanyaan : Saya kesulitan dengan penggunaan aplikasi kelas online

Dari hasil pengolahan data yang terlihat pada gambar 1 dan gambar 2, untuk mahasiswa Telkom University sebanyak, $34 \%$ merasakan kesulitan menggunakan aplikasi yang di minta dalam perkuliahan online dan sekitar $21 \%$ menjawab ragu-ragu, dan 45 orang tidak setuju artinya tidak kesulitan penggunaan aplikasi ini. Adapun untuk mahasiswa UIN SGD Bandung, sebanyak $31 \%$ merasa kesulitan, sekitar $19 \%$ menjawab raguragu, dan sebanyak $50 \%$ yang menjawab bahwa tidak kesulitan menggunakan aplikasi ini. Analisa dari data tersebut secara umum para mahasiswa masih gagap menggunakan apikasi online dalam perkuliahan tidak lebih dari $50 \%$ hal yang menarik mahasiswa UIN SGD lebih familiar dibanding mahasiswa Tel $\mathrm{U}$ walaupun tidak dengan gap yang besar, hal ini bisa juga disebabkan karena mahasiswa UIN yang masuk sesuai dengan umumnya ada seleksi masuk perguruan tinggi negeri dan lewat jalur undangan bagi mahasiswa yang berprestasi. Hal yang perlu menjadi perhatian dari data ini, menyangkut mahasiswa yang ragu dan mengalami kesulitan sebesar sebanyak $56 \%$ mahasiswa Tel U dan $50 \%$ mahasiswa UIN, karena perkuliahan online kemungkinan masih menjadi alternatif saat ini ketika wabah COVID-19 masih merajalela, dan bahkan hampir semua perguruan tinggi melakukan perkuliahan online sampai pemerintahan dalam hal ini, MENDIKBUD memutuskan kuliahan tatap muka lagi, walaupun perkuliahan online ini bagi perguruan tinggi tertentu akan menjadi alternatif perkuliahan kedepan institusinya. Analisa lanjutan dari data ini, sebagai peringatan kepada institusi perguruan tinggi segera melakukan terobosan alih teknologi melalui berbagai pelatihan penguasaan penggunaan aplikasi ini. Jikalau terlambat maka akan menjadi beban kelancaran perkuliahan yang berakibat keberbagai kebijakan serta berimbas kepada nilai akreditasi perguruan tinggi tersebut 
sebagai catatan penelitian dilakukan kepada mahasiswa tingkat 2 semester 3 artinya mahasiswa katagori mahasiswa baru atau masih proses peralihan. Hal yang perlu perhatian dari peristiwa ini dampak kepada mental mahasiswa, manakala masalah ini tidak segera dicarikan solusinya, sebagaimana analisa dipertanyaan pertama, ini akan menjadi jalan kegagalan studi mahasiswa.

3) Pertanyaan: Dosen memberikan tugas yang berlebih daripada pembelajaran dikelas.

Mahasiswa Telkom University sebanyak $47 \%$ sangat mendukung untuk pertanyaan ini artinya dosen agar bijak untuk memberikan tugas dengan suasana ini, disamping itu bagi mahasiswa tingkat ini masih diberikan beban paket mata kuliah sekitar 20-22 SKS atau sekita 7 atau 8 mata kuliah yang kesemuanya ada tugas, dosen perlu hati-hati dalam kontek ini, sekitar $23 \%$ menjawab ragu-ragu, biasanya yang mahasiswa kelompok ini cenderung kepada mahasiswa yang tidak mau beban tugas yang banyak. dan 30 orang tidak masalah dengan tugas yang diberikan, artinya dengan kesiapannya bisa melakukan dan menyelesaikan tugas ini. Mahasiswa UIN SGD Bandung, sebanyak $72 \%$ menjawab setuju artinya mahasiswa sepakat bahwa tugas dosen terlalu banyak yang diberikan hal ini bisa membuat stress mahasiswa, ini perlu menjadi perhatian yang mendalam karena mahasiswa yang menjawab diatas $50 \%$, hal yang sama dengan analisa untuk mahasiswa Tel-U. Maka UIN pun harus melakukan terobosan dan pengingatan kepada para dosennya agar tanggap dan bijak dalam pembebanan tugas kepada para mahasiswanya. Hal ini akan menjadi besar manakala mahasiswa yang $13 \%$ menjawab ragu-ragu cenderung ke keberatan atas beban tugas yang diberikan, dan sebanyak $13 \%$ yang menjawab bahwa tidak keberatan dengan tugas yang diberikan. Analisa lanjutan dari data yang menjawab tidak keberatan atas beban tugas, pihak perguruan tinggi bisa melakukan pendekatan akademis kepada mereka melalui para dosen atau aturan lewat prodi masing-masing untuk mengoptimalkan peran mereka membantu para mahasiswa lain dengan berbagai kegiatan yang di fasilitasi kampus atau dengan kreatifitas mereka sendiri yang terpantau, karena kalau tidak tertangani akan menjadi beban kejiwaan bagi para mahasiswa sepert ini mengalami kelainan kejiwaan disebabkan karena stres berkelanjutan.

4) Kalau memikirkan tugas kadang saya susah tidur

Melihat data diatas, baik dari mahasiswa Telkom University sebanyak, $70 \%$ menjawab setuju yang artinya mengalami kesulitan tidur ketika memikirkan tugas, sekitar $17 \%$ menjawab ragu-ragu, dan 13 orang tidak setuju artimya tidak merasakan kesulitan tidur. Adapun untuk mahasiswa UIN SGD Bandung, sebanyak $50 \%$ merasa kesulitan, sekitar $13 \%$ menjawab ragu-ragu, dan sebanyak $38 \%$ yang menjawab bahwa tidak setuju artinya tidak merasa kesulitan untuk tidur jika teringat tugas. Analisa dari data tersebut jika mahasiswa Telkom University yang ragu ragu juga dimasukkan ke katagori ini sehingga mencapai $87 \%$. Ini menemukan benang merahnya bahwa beban tugas yang berlebih, besar kemungkinan akan berakibat stres, walaupun pada tingkat stress rendah, sedang dan berat tergantung bagaimana para mahasiswa memaintance dirinya dari permaslahan ini sehingga menemukan formula penyelesaiannya. Hal yang sama nalisanya dengan mahasiswa UIN Bandung. Ada hal yang menarik bahwa mahasiswa UIN, tidak merasakan kesulitan tidur, karena beberapa faktor, menurut peneliti bahwa mahsiswa UIN banyak berlatar belakang dari berbagai sekolah islam dan pesantren sehingga pengelolaan emosional dan stres di imbangi dengan perjalanan spiritual keagamaan yang dimilikinya.

5) Saya suka kuliah tatap muka dikelas langsung dari pada kuliah online

Hal yang menarik pada pertanyaan ke lima ini, mahasiswa Telkom University sebanyak, $90 \%$ sangat setuju dengan perkuliahan tatap muka, sekitar $10 \%$ menjawab ragu-ragu, dan tidak ada orang tidak setuju dari pertanyaan ini. Adapun untuk mahasiswa UIN SGD Bandung lebih banyak lagi, sebanyak $94 \%$ merasa setuju perkuliahan tatap muka di 
kelas, tak satupun menjawab ragu-ragu, dan sebanyak $6 \%$ yang menjawab bahwa tidak setuju perkuliahan tatap muka. Analisa dari data tersebut hampir mayoritas para mahasiwa rindu dengan perkuliahan tatap muka dikelas, walaupun sebagian dari mereka siap dengan perkuliahan online. Data ini akan lebih menarik ketika para peneliti melakukan analisa dengan tinjauan berbagai disiplin ilmu, ini akan menemukan temuantemuan baru yang sangat menyentuh dan bermanfaat. Akan tetapi untuk penelitian ini, peneliti mencoba mengurai tentang fenomena ini, kenapa dikatakan fenomena karena beberapa kampus yang disurvei walaupun hasilnya tidak ditampilkan disini, jawabannya diatas $90 \%$ mereka ingin kuliah tatap muka, sebenarnya kalau dilihat dengan kacamata sistem pendidikan yang melibatkan guru atau dosen, ada nilai yang tidak bisa di rasakan, dibayangkan dengan kata-kata dan tampilan fisik akan tetapi ini mendalam, diantarnya disini ada pengormatan, kecintaan, persaudaraan, kasih sayang serta kerinduan bertemu langsung yang terjadi antara mahasiswa dengan dosennya, entah karena ini penelitian di Indonesia yang mayoritas beragama Islam. Ajaran Islam mengajarkan sifat-sifat diatas, penghormatan guru/dosen dari mahasiswa mirip penghormatan kepada orang tuanya

\section{Kesimpulan}

Hasil dari penelitian ditemukan hubungan yang erat antara perkuliahan online dengan sikap mental dari para mahasiswa peserta perkuliahan. Hal ini bisa dilihat dari data hasil pengolahan dan analisannya menunjukkan sekitar rata-rata dari data yang didaptkan dari dua kampus diatas, sekitar $60.5 \%$ mahasiswa dari perguruan tinggi yang menjadi objek penelitian siap berdaptasi dengan perkuliahan online walaupun ada yang merasa kesulitan dalam penggunaan aplikasi yang dipakai sebanyak diangka $32.5 \%$ tapi sekitar $47.5 \%$ siap beradaptasi. Hal ini bisa diatasi melalui pelatihan yang cepat dalam penggunaan teknologi pendukung serta operasionalisasi aplikasi tersebut. Perkuliahan online yang dilakukan para dosen disertai dengan pemberian tugas yang banyak dalam kondisi merebaknya wabah COVID-19, dan kebijakan pemerintahan anjuran stay at home serta working from home, hal ini membuat para mahasiswa sulit bergerak, tidak seperti biasanya dalam menyelesaikan tugasnya melalui interaksi antar mahasiswa dengan frekuensi yang tinggi, sekitar $59.5 \%$ keberatan atas tugas yang diberikan dosen dimasa pandemik ini, sehingga sumber rujukannya hanya sebatas akses internet, bagi mahasiswa yang sudah faham penguasaan teknologi IT dan kemampuan akdemis baik, hal ini bukan menjadi persoalan. Disamping itu kondisi ini akan membuat tekanan psikologis bagi para mahasiswa data disurvey menunjukan mahasiswa yang mengalami kesulitan tidur karena dampak tugas ini sekitar $60 \%$ yang merupakan perhitungan rata-rata dari dua kampus tersebut. Kalau hal ini dibiarkan terus akan berakibat fatal dalam perkembangan kejiwaan mahasiswa, dampaknya kegagalan studi atau drop out dan hal lain yang lebih parah. Untuk itu perlu kiranya fihak perguruan tinggi membuat kebijakan menyelesaikan masalah ini, dengan berbagai program alih teknologi yang cepat kepada para mahasiswa tentang teknologi pembelajaran dengan penggunaan aplikasi perkuliahan yang dipakai, serta melakukan pendekataan penyelesaian penyakit mental jika ada yang terganggu kejiwaannya melalui Lembaga bantuan khusus. Hal yang menarik dari penelitian ini menunjukkan sebanyak $92 \%$ mahasiswa memilih dan lebih suka perkuliahan tatap muka di kelas di banding perkuliahan online. Analisa ini bisa dipakai oleh semua perguruan tinggi di Indonesia maupun Dunia untuk menemukan formulasi yang tepat tentang sisitem perkuliahan online ke depan, untuk memasukkan, membahas dalam kajian, menyertakan serta menjawab dalam kebijakan yang diambil menjadi program kerja sistem pendidikan ke depan yang komprehensip ditinjau dari berbagai sisi.

Dari data-data diatas, banyak sekali peluang penelitian kedepan menyangkut sistem pembelajaran yang efektif pada masa COVID-19 ini dengan penggunaan teknologi yang terbaru, serta bagaiman sistem pembelajaran yang dilakukan jikalau terjadi bencana serta teknologi yang ada tidak bisa dipakai. 


\section{Daftar Pustaka}

[1] Dias, M.O., Lopes, R.”Will the COVID-19 Pandemic Reshape our Society?" EAS Journal of Humanities and Cultural Studies). April 2020, Vol.2, Issue 2, pp. 93-97. ISSN: 2663-6743 (Online). DOI: 10.36349/EASJHCS. 2020.V02I02.013.

[2] World Health Organization, 2020, WHO Director-General's opening remarks at the media briefing on COVID-19 - 11 March 2020. Accessed March 11, 2020. https://www.who.int/dg/speeches/detail/who-director-general-s-opening-remarks-atthemedia-briefing-on-covid-19 .March-2020.

[3] Chen, S., Zhang, Z., Yang, J., Wang, J., Zhai, X., \& Bärnighausen, T., et al. (2020). Fangcang shelter hospitals: a novel concept for responding to public health emergencies. The Lancet. https://doi.org/10.1016/S0140-6736(20)30744-3.

[4] Ms. Veena Shenoy, Ms. Sheetal Mahendra, Ms. Navita Vijay." COVID 19 - Lockdown: Technology Adaption, Teaching, Learning, Students Engagement and Faculty Experience”. Mukt Shabd Journal. April 2020. Volume IX, Issue IV, APRIL/2020 ISSN NO : 2347-3150.

[5] Nur Rohim Yunus, Annissa Rezki, "Kebijakan Pemberlakuan Lockdown Sebagai Antisipasi Penyebaran Corona Virus Covid-19". Jurnal Sosial \& Budaya Syar-i FSH UIN Syarif Hidayatullah Jakarta, 2020. Vol. 7 No. 3, pp.227-238, DOI: 10.15408/sjsbs.v7i3.15083-227.

[6] Thomas L. Friedman.” The World Is Flat 3.0: A Brief History of the Twenty-first Century. I, New York, 2005: pp. 491-501.

[7] Agus Kusnayat, Agus Sofwan.'Komputer dan Internet: Media Percepatan Penguasaan Materi Perkuliahan". Vocational Education In IT Polytechnic To Meet The Industrial Requirement With Campus. Bandung, 17 Desember 2009. Hal.1-5.

[8] Leslie, H. (2019), "Trifecta of Student Engagement: A framework for an online teaching professional development course for faculty in higher education", Journal of Research in Innovative Teaching \& Learning, Vol. aheadof-print No. ahead-of-print. https://doi.org/10.1108/JRIT-10-2018-0024.

[9] Darmalaksana, W., Hambali, R. Y. A., Masrur, A., \& Ushuluddin, F. (2020). Analisis Pembelajaran Online Masa WFH Pandemic Covid-19 sebagai Tantangan Pemimpin Digital Abad 21. pp.1-12.

[10] Giorgi Basilaia, David Kvavadze." Transition to Online Education in Schools during a SARS-CoV-2 Coronavirus (COVID-19) Pandemic in Georgia”. Pedagogical Research, April 2020. https://doi.org/10.29333/pr/7937.

[11] Denissa Alfiani, dkk. 2016. Pembelajaran Berbasis Video Untuk Anak Generasi Z.Prosiding Inovasi Pendidikan di Era Big Data dan Aspek Psikologinya .ISSN: 25485407. PascaSarjana Universitas Negeri Malang. hal 85-92.

[12] Boidurjo Rick Mukhopadhyay,Bibhas K Mukhopadhyay." COVID-19 and 'Zoom' for Remote Teaching: Enhancing Student Engagement". May 2020. https://www.researchgate.net/publication/341151549.

[13] Ismail Akbar Brahma.” Penggunaan Zoom Sebagai Pembelajaran Berbasis Online Dalam Mata Kuliah Sosiologi dan Antropologi Pada Mahasiswa PPKN di STKIP Kusumanegara Jakarta”. Jurnal Ilmu Pendidikan Nonformal. Mei 2020. Volume 06 No. 02. http: //ejurnal.pps.ung.ac.id/index.php/AKSARA/index.

[14] Jaka Wijaya Kusuma, Hamidah.” Perbandingan Hasil Belajar Matematika Dengan Penggunaan Platform Whatsapp Group Dan Webinar Zoom Dalam Pembelajaran OnlinePada Masa Pandemik COVID 19". Jurnal Ilmiah Pendidikan Matematika,2020. Volume 5 Nomor 1 P-ISSN: 2502-7638; E-ISSN: 2502-839.

[15] La Ode Anhusadar." Persepsi Mahasiswa PIAUD terhadap Kuliah Online di Masa Pandemi Covid 19". Journal of Islamic Early Childhood Education. April 2020. ISSN: 
2621-0339. e-ISSN: 2621-0770, hal. 44- 58 Vol. 3, No. 1, DOI: http://dx.doi.org/10.24014/kjiece.v3i1.9609.

[16] Dhia Fauzia Rahman, Kirana Mukharomah, Nurul Qomariah,Wardah Hafidz Maesafaroh, Dian Eky Pratiwi.” Penggunaan Analitik Hirarki Proses Dalam Menentukan Preferensi Platform Pembelajaran Daring Selama Masa Tanggap Darurat COVID-19 Pada Mahasiswa UGM Yogyakarta".April 2020 DOI: 10.13140/RG.2.2.11562.98248.

[17] Conrad Hughes." Some implications of COVID-19 for remote learning and the future of schooling". April, 2020, No.36 - IBE-UNESCO.

[18] Chakraborty, M. and Muyia Nafukho, F. (2014), "Strengthening student engagement: what do students want in online courses?", European Journal of Training and Development, Vol. 38 No. 9, pp. 782-802. https://doi.org/10.1108/EJTD-11-2013-0123.

[19] Abdel-Fattah HMM." Emotional Intelligence and Emotional Stability in Crises". Journal of Psychiatry and Psychiatric Disorders. April 2020, Volume 4, Issue 2. Doi: 10.26502/jppd.2572-519X0090.

[20] Jalloh, M. F., Li, W., Bunnell, R. E., Ethier, K. A., O Leary, A., \& Hageman, K. M., et al. (2018). Impact of Ebola experiences and risk perceptions on mental health in Sierra Leone, July 2015. BMJ Global Health, 3(2), e471. http://dx.doi.org/10.1136/bmjgh2017-000471.

[21] Liu, S., Yang, L., Zhang, C., Xiang, Y., Liu, Z., \& Hu, S., et al. (2020). Online mental health services in Cina during the COVID-19 outbreak. The Lancet Psychiatry. 26 https://doi.org/10.1016/S2215-0366(20)30077-8.

[22] Wen Li1, Yuan Yang, Zi-Han Liu, Yan-Jie Zhao, Qinge Zhang, Ling Zhang, Teris Cheung, Yu-Tao Xiang. "Progression of Mental Health Services during the COVID-19 Outbreak in Cina”. International Journal of Biological Sciences 2020; 16(10): 17321738. doi: 10.7150/ijbs.45120.

[23] Lee, S. M., Kang, W. S., Cho, A., Kim, T., \& Park, J. K. (2018). Psychological impact of the 2015 MERS outbreak on hospital workers and quarantined hemodialysis patients. Comprehensive Psychiatry, 87, 123-127.

[24] Li Duan, Gang Zhu." Psychological interventions for people affected by the COVID-19 epidemic". psychiatry Vol 7 April 2020. https://doi.org/10.1016/ S2215-0366(20)300730

[25] Kang, L., Li, Y., Hu, S., Chen, M., Yang, C., \& Yang, B. X., et al. (2020). The mental health of medical workers in Wuhan, Cina dealing with the 2019 novel coronavirus. The Lancet Psychiatry, 7(3), e14. https://doi.org/10.1016/S2215-0366(20)30047-X.

[26] Xiang, Y., Yang, Y., Li, W., Zhang, L., Zhang, Q., \& Cheung, T., et al. (2020). Timely mental health care for the 2019 novel coronavirus outbreak is urgently needed. The Lancet Psychiatry, 7(3), 228- 229.

[27] Shuai Liu, Lulu Yang, Chenxi Zhang, Yu-Tao Xiang, Zhongchun Liu, Shaohua Hu, Bin Zhang." Online mental health services in Cina during the COVID-19 outbreak". Lancet Psychiatry 2020 . February 18, 2020 https://doi.org/10.1016/ S2215-0366(20)30077-8

[28] Bao, Y., Sun, Y., Meng, S., Shi, J., \& Lu, L. (2020). 2019-nCoV epidemic: address mental health care to empower society. The Lancet. https://doi.org/10.1016/S01406736(20)30309-3.

[29] Huang, Y., \& Zhao, N. (2020). Generalized anxiety disorder, depressive symptoms and sleep quality during COVID-19 epidemic in Cina: a web-based cross-sectional survey. medRxiv. https://doi.org/10.1101/2020.02.19.20025395.

[30] Sugiyono.” Metode Penelitian Pendidikan”. Edisi ke-3: Bandung, 2019: 14-28.

[31] Abdul Karim Zaidan. "Hikmah Kisah-Kisah Dalam Alquran, Jakarta, DarusSunah, 2010, hal. 545 